\title{
Listening to the Objects --Analysis of LI Wei's Installation Art
}

\author{
Xiaofeng Liu ${ }^{1, \text { a }}$, Liang Shang ${ }^{2}$ \\ ${ }^{1}$ College of Publishing \& Printing and Art \& Design, University of Shanghai for Science and \\ Technology, Shanghai, China \\ ${ }^{2}$ Fine Arts School Affiliated to Central Academy of Fine Arts, Beijing, China \\ a151693023@qq.com
}

Keywords: LI Wei; Installation art; Mono-ha style.

\begin{abstract}
LI Wei is a young contemporary artist from Shanghai. He works in the university, and he is on behalf of academism. LI Wei combines oriental philosophy with characteristics of western art in his installation art works. In an exhibition named "Once in Lifetime", his works typically reflect the fusion of Chinese and western culture. The author analyzes three clues from his works through the interview at exhibition hall, as well as the careful analysis of his works. These three clues connect LI Wei's former and latter works together, and help us to sum up the artist's style and the factors that influence his style.
\end{abstract}

\section{Introduction [1]}

Installation art was popular in 1960s. From Duchamp's "Spring", we learned that the commonly used expression methods in installation art are symbolism and metaphor, which were similar to Japanese Mono-ha art. But there's also difference between these two kinds of art. Almost all the postmodernism art works, both Installation and Mono-ha art, have the characteristics of blurred boundary and mutual confluence. The interpretations of a work also vary from person to person. The works of Shanghai young artist, LI Wei, reflect the typical fusion of Chinese and western culture. In his works, audience can find both the explicit expression in Western culture and the implication in Chinese philosophy. This feature is totally expressed in his exhibition "Once in Lifetime". This exhibition is an experimental one, and it is also a discussion on fusion of Chinese and western philosophy in art. Complex clues contained in his works offer viewers greater space to guess and interpret this exhibition.

\section{Analysis of LI Wei's Art Works from "Once in Lifetime" [2]}

The Exhibition of "Once in Lifetime". [3] There are seven pieces of art work in this exhibition. Most of them are represented through video, installation and photos. In this exhibition, LI Wei uses elements such as iron, wood, plastic and bacteria repetitively to build the sight in his heart. The most important feature of "Once in Lifetime" is that none off these seven works is titled. Artists often name their work "untitled" to show their attitude, but LI Wei did not label these works at all. This is rare. He explains that, "Once in the Lifetime" is the name both for exhibition and for all the works. This phenomenon catches audiences' curiosity easily. Because it means that these seven works are not only individual works, they also belong to a much bigger work. All the audience in this exhibition find themselves in a huge work of art. When visitors enter the exhibition hall, streamline and repeated elements give them the feeling of consistency and integrity. Moreover, the absence of names brings obstacle to audiences, but this obstacle also brings pleasure in appreciating his works. Only the careful analysis of works can help the audience to discover the delicacy of each work. For example, the audience can see the growing hyphae in the dark, dead wood. These hyphae seem inadvertent, but they are actually the hint created by the artist. LI Wei's works become more complete with these hints.

Analysis on LI Wei's Art Works. Teacher's influence. [4] LI Wei was born in Jilin, so he is frank and forthright as a "northerner". Since childhood, he has had a unique perspective and special, personal thinking method of the surrounding things. He is easy to be attracted by details from nature. 
In the Watercolor Painting Department of Lu Xun Fine Arts Institute, he studied western painting and got familiar with the thinking methods of western painting. The traditional thinking mode of pictures influenced his view on postmodernism arts. So in his young age, he maintained a relatively conservative attitude towards postmodernism. His attitude changed when he met his Japanese tutor Toyomi HOSHINA. The teacher really opened the door of installation art for him. Now Toyomi is the dean of Fine Arts Department of Tokyo Art University, he is also a representative figure of contemporary Japanese Moho-ha art. Toyomi emphasizes the real life; his works are full of his own emotional experience. For example, in his "Burning Memories", he recreated his childhood experience and memory of fire in the gallery, and shared with the audience with his own memory and unique experience. In "Memory of Water", he used ink and local water rub to print poetic images of rock texture changes. These are his feelings of nature. He is willing to share the beauty of nature through his art. The teacher inspired LI Wei. On the view of human and nature, they share similar attitude. LI Wei also cares about emotion expressing and experience sharing in his works. Zen in China advocates "go where life takes you". LI Wei summarized this unspeakable feeling, and put it in his works as "accidents". He also stresses contingency in his works repeatedly. In Japan, LI Wei finds that all people's life remains the same day by day. Every hour is counted in plans and arrangements. This kind of life is efficient and fast paced. He thinks that it is the philosophy of western people and the production of modernism, which is not consistent with oriental philosophy. LI Wei believes that the days without modern science and technology are quite good. There are no mobile phones, and we do not need to accurate to every minute, even second. People gazed stars and communicated with the nature day after day. Although this backward idea is too idealistic, we can be seen LI Wei's sensibility and insular attitude. This philosophy of "following the fate" is actually the pursuit of humanity and freedom. This spirit also reflected as the criticism of institutional constraints to people's modern life. This kind of criticism is quite common in his works. This is LI Wei's value of life. Following the fate and paying attention to encounters. It helps people to cherish each other.

Mono- ha art in the nature. [2] [3] [5] Art emphasizes the natural properties of material, but it pays more attention to the ductility of raw materials. Master of Mono-ha art, Sekine Nobuo expressed the ductility of the material in his work "phase - the earth". In LI Wei's works we also can find that. He pays a lot of attention to the properties and possibilities of materials. For the material itself, he also constantly explores the new expression of language. Encounters are important in LI Wei's philosophy. He encounters a stick in the east village of Suzhou. East village is an old village, in which you can hear a lot unofficial history about the Qianlong emperor. This piece of wood was once a beam in the most luxurious house in this village. The family has suffered a lot and broke-down in these years. When LI Wei encountered this stick, it lay in a heap of ruins quietly. The artist brought it back to the studio and processed it. He combined the Japanese lacquer art in this work, and varnished the wood with black painting. The unchanged appearance of wood is his respect to it. By the change of its location from east village to the gallery, the deadwood carries stories itself. It sends out the aroma of time, and witnesses the glory of history. The decay of wood symbolizes the current situation of Suzhou east village. The story of deadwood can be told by the wood itself. Listening to the objects help to tell their stories, which is the first layer of object language in LI Wei's creation.

If "listening to the objects to tell their stories" is poetic and idealism, the second layer of object language is the feeling the texture of material. Different materials have different properties which will directly influence person's inner feeling. Metal expresses cold feeling, while cotton and linen can give persons feelings of warmth. As what has shown in Figure 1, the black block put together with cast iron. Wood has vivid, irregular, natural lines, while iron is rigorous, square shaped industrial legacy. The comparison between the decaying, incomplete wood and strong, cold iron is actually the differences among man, nature and industry. It seems that the wood is dead and decaying, while the steel is eternal and hard. But from careful observation audiences can find, there are hyphae (Figure 2) on the wood while cast iron is rusting. This is the second layer of contrast. Hyphae are symbols of life, and rust is the representative of death. In this layer, the artist wants to express that the industrial age cannot be long-lasting as natural cycle of life. Listening to the objects and feeling the difference 
between the materials both take place in LI Wei's given situation, and need the viewers to slowly appreciate.

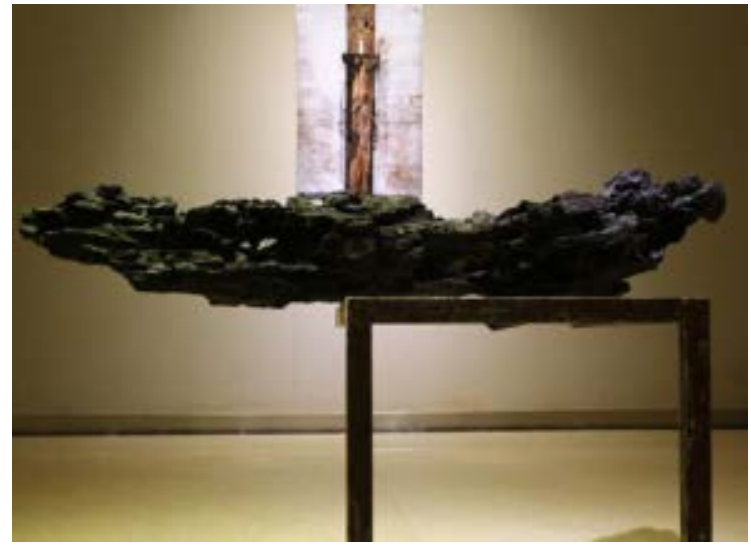

Figure 1

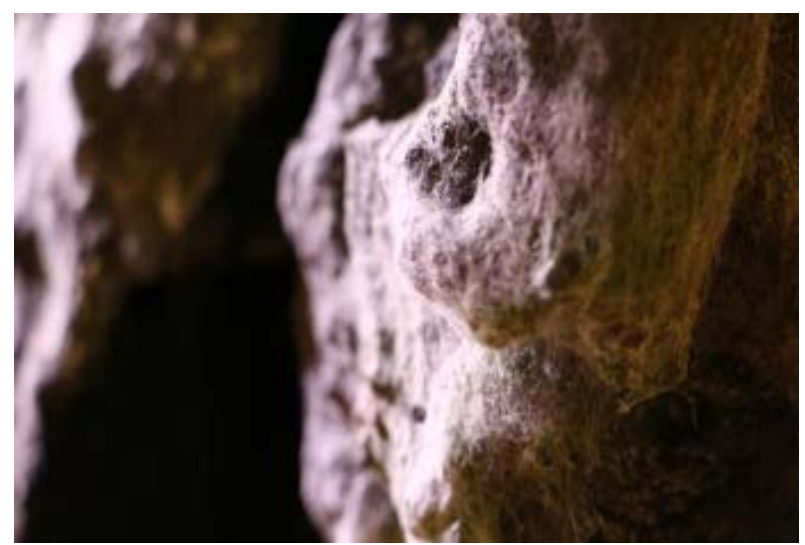

Figure 2

The image of white tower. [5] In the exhibition, audience can see a glowing image of white tower (Figure 3) in the hall on second floor. The image of white tower appears repeatedly in LI Wei's works. This symbol has become an important clue to interpret his works. In his early exhibition in Tokyo named "Flow Regeneration", Li Wei used white tower elements. This symbol derived from LI Wei's own experience. Once, he saw a statue of white tower in the street, and he was attracted by its unique figure. After inspection he found that, the white tower was an adornment from the period of Republic of China, and it was used to contain pomade. This experience means a lot to LI Wei. He thinks this is a kind of fate calling. Buying the white tower is not only his own choice, but also the white tower's. Accidental factors are one of the reasons of his choosing on white tower. Secondly, the tower belongs to Buddhist architecture. It is often used to contain or collect the bones, images and scriptures of Buddha. The tower represents the spirit of Buddhism, and it is also a kind of philosophy of human's behaviors. This spirit accords with LI Wei's pursuit of detached state of mind. At that time he was struggling to find appropriate elements to express his ideas. Then, this seemingly unrelated white tower becomes an important symbol which appears repeatedly in his works.

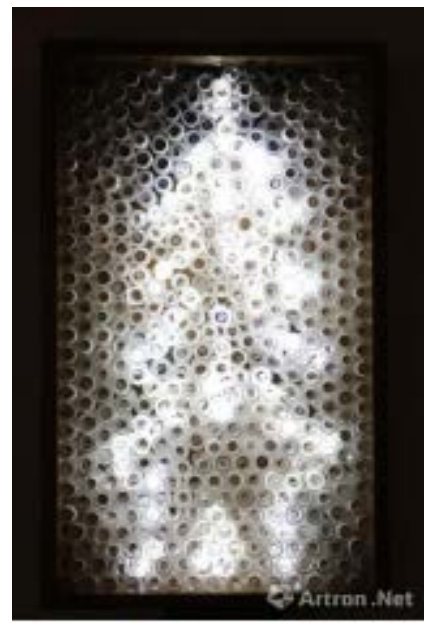

Figure 3

Hujiang gallery. Mono-ha art often discusses the relationship between objects and space. In "Once in lifetime", LI Wei combined his works with exhibition space skillfully. The exhibition space is Hujiang gallery, which was once the hospital of Hujiang University. It is built by Germans and has over one hundred year history. At that time, the first floor was diagnosing room, and the operating room located on the second floor. There are always a lot of stories associated with life and death in hospitals. The art gallery is not an exception. LI Wei holds this period of history and the represents it through visualization, and then diverts it to his own work. The history and integration of space and 
time are presented to the audience. From Figure 4 we can see, the work is made up of four parts. In the middle position there is a prayer wheel (Figure 5). The cylinder is filled with broken porcelain pieces solidified by glue. White tower image is hung on east wall and the floor is covered by electrocardiograph pictures. Here, the prayer wheel represents samsara, glowing white tower is the light of life. The electrocardiograph means the existence of life. All of these indirectly contacted with hospital. LI Wei fused the history of museum in his works, the different time and space elements rub up together to form a single language. This is the artist's thinking of life, death, rebirth, fate, time and bygones.

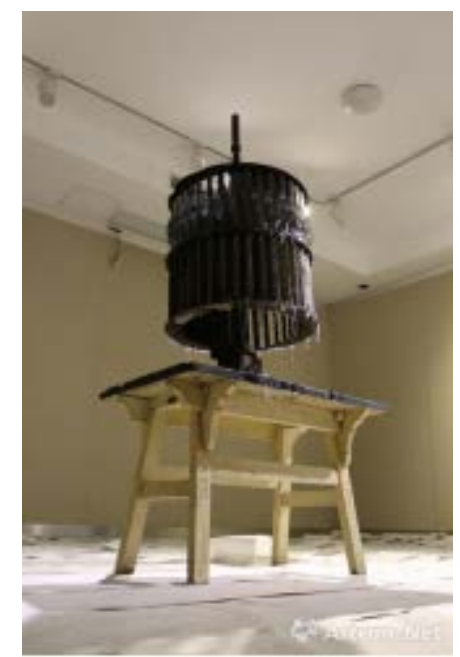

Figure 4

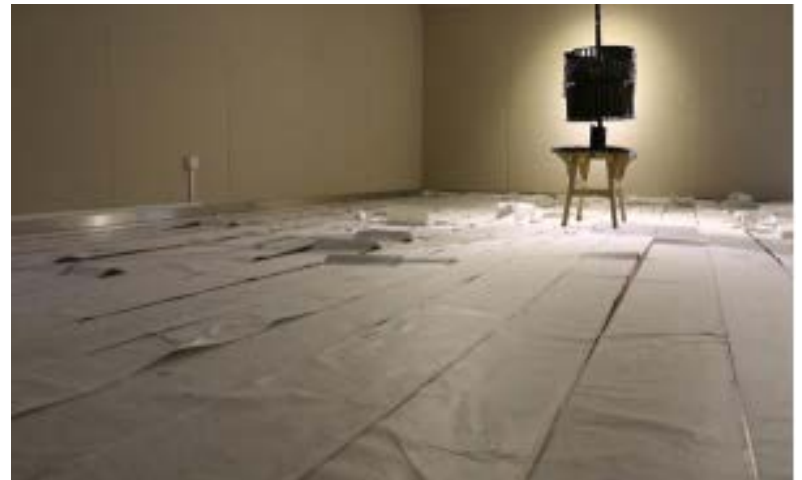

Figure 5

LI Wei's installation art works blends explicit expression in Western culture and the implication in Chinese philosophy. He moved the deadwood from east village into the art museum, and displayed it without adornment. This reflects the western-style directness. The hyphae on the wood are representation of Oriental implication. The difference on textures of wood and iron show western directness, and latent hyphae and rust are implicit Oriental symbols. Every piece of his work seems an independent subject, and there is no link between each other. But after careful analysis, it can be found that LI Wei's works all touches the topic of relationship between human and nature. The electrocardiogram and hyphae are symbols of life, white tower and prayer wheel represent reincarnation. In Figure 1, it seemingly tells of victory of industrial age, but it actually implicates the cycle of life from beginning to decay. So all LI Wei's works express criticism of life system, but this criticism is based on his inner understanding of nature and life.

\section{Summary}

LI Wei is lucky. His tutor's enlightenment and his own efforts make his artistic works successful, just as the old Chinese saying goes, "A canal is formed when water comes." For him, the success of exhibition is mere the appearance. After the busy and noisy daytime, he prefers to quietly listen to object's language at night. Different objects tell their own stories. While facing with challenges, he never refutes. Actually, understanding LI Wei's works is quite simple and the best way is listening.

\section{Acknowledgement}

Fund project: This paper is supported by Foundation for Humanities and Social Science of University of Shanghai for Science and Technology (Project No.: 16HJSK-YB01) and Foundation for Teachers' Teaching Development of University of Shanghai for Science and Technology (Project No.: CFTD16046Y).

\section{References}

[1] XU Gan. What is Installation Art [J]. Art Observation, 2000, 11: 69-73. 
[2] YE Xiang-dong. Creation from the Concept of Installation Art [J]. Literature and Art Studies, 2005, 03: 154-155.

[3] HE Wan-li. On Contemporary Domestic Installation Art [J]. Literature and Art Studies, 1998, 01: 127-136.

[4] LUO Cai. The Formation and Evolution of Mono-ha Art [J]. Art Observation, 2013, 03: 121-128.

[5] SHEN Ye. The Localization Tendency of Chinese Installation Art [J]. New Arts, 2015, 02: 122-125. 